\title{
Penerapan Kekayaan Intelektual (KI) Terhadap UMKM sebagai Upaya Mewujudkan Persaingan Bisnis Berkeadilan
}

\author{
Sulasno \\ Program Studi Ilmu Hukum, Universitas Serang Raya, Serang. \\ Email : sulasno1971@gmail.com
}

Info Artikel:

| Diterima: 18 Desember 2018

| Disetujui: 28 Desember 2018

| Dipublikasikan: 31 Desember 2018

\begin{abstract}
The existence of Micro, Small and Medium Enterprises (MSMEs) has a big contribution in advancing the economy of this nation. The growth and development of these MSMEs is able to drive the pace of the creative economy in the real sector and can be felt very beneficial in terms of the distribution of people's income. Especially if the product of the MSME product already has legal Intellectual property rights in its protection. Utilization of role of Intellectual Property by business actors towards UMKM products not yet maximal. The uneven understanding that Intellectual Property as the need for Protection makes many MSME products not yet registered. In addition, cost constraints and access difficulties are also considered as other causes. The research was made to answer the problem: 1) How is the Implementation of Intellectual Property Protection (KI) on the products of Micro, Small and Medium Enterprises (MSMEs)? 2) What is the role of the Government of Intellectual Property Protection (KI) on MSME products? The research method is carried out qualitatively with Descriptive-Normative analysis where Law acts as Norm / Rule / Legislation. Techniques Data collection by searching the literature and keeping in mind the prevailing reality. Result of the Research that in order to provide Legal Protection against UMKM products, the Government should play a role in facilitating the registration, relief and easy access to registration and socialization of Intellectual Property

Keywords: UMKM Products, Protection, Intellectual Property.
\end{abstract}

\begin{abstract}
Abstrak
Adanya Usaha Mikro Kecil dan Menengah (UMKM) mempunyai andil besar dalam memajukan roda perekonomian bangsa ini. Pertumbuhan dan perkembangan dari UMKM tersebut mampu mendorong laju ekonomi kreatif di bidang sector riil serta dapat dirasakan sangat bermanfaat dalam hal pendistribusian pendapatan masyarakat. Apalagi bila dalam produk produk UMKM tersebut sudah mempunyai hak kekayaan Inteletual secara hukum dalam perlindungannya. Pemanfaatan peranan Kekayaan Intelektual oleh pelaku usaha terhadap produk-produk UMKM belum maksimal. Belum meratanya pemahaman bahwa Kekayaan Intelektual sebagai kebutuhan terhadap Pelindungan membuat banyak produk-produk UMKM yang belum didaftarkan. Selain itu kendala biaya dan kesulitan akses dianggap juga sabagai penyebab lainnya. Penelitian dibuat untuk menjawab permasalahan : 1) Bagaimana Penerapan Kekayaan Intelektual (KI) terhadap produk Usaha Mikro, Kecil dan Menengah (UMKM)? 2) Bagaimana Peranan Pemerintah terhadap penerapan Kekayaan Intelektual (KI) terhadap produk-produk UMKM ? Metode Penelitian dilaksanakan secara Kualitatif dengan analisis Deskriptif-Normatif dimana Hukum bertindak sebagai Norma/Kaidah/Perundang-undangan. Teknik Pengumpulan data dengan melalui penelusuran literatur dan tetap memperhatikan kenyataan yang berlaku. Hasil Penelitian bahwa dalam rangka memberikan Pelindungan Hukum terhadap produk-produk UMKM, maka Pemerintah selayaknya berperan memberikan kemudahan dalam pendaftaran, keringanan, dan kemudahan akses terhadap pendaftaran dan sosialisasi Kekayaan Intelektual
\end{abstract}

Kata Kunci : Produk UMKM, Perlindungan, Kekayaan Intelektual. 


\section{A. PENDAHULUAN}

Perkembangan bisnis pada
akhir akhir ini mengalami
perkembangan yang cenderung
membaik dari tahun ke tahun,
terutama pada sector usaha mikro
kecil dan menengah (UMKM).

Kedudukan UMKM telah lama diakui eksistensinya sebagai usaha yang sangat vital, karena UMKM tersebut mempuyai peran yang sangat besar dalam memajukan perekonomian Indonesia. Selain itu UMKM itu sebagai langkah solutif untuk mengurangi atau bahkan menanggulangi pengangguran atau kemiskinan. Dengan pemberdayaan UMKM tersebut diharapkan dapat dan mampu untuk meningkatkan atau bahkan mensejahterakan masyarakat Indonesia. Walau dengan segala yang ada UMKM masih sangat banyak kekurangan terutama dalam modal usaha untuk pengembangannya.

Kegiatan bisnis UMKM tersebut merupakan bagian integral dari kehidupan masyarakat. Karena kegiatan bisnis adalah kegiatan manusia seperti kegiatan yang dilakukan oleh manusia lainnya. ${ }^{1}$ Dengan adanya kegiatan bisnis yang dilakukan, maka tentu bagian dari kegiatan bisnis adalah terciptanya produk-produk usaha. Masing-masing pelaku usaha akan bersaing dalam menciptakan, dan memasarkan produk mereka. Produk-produk usaha tentu akhirnya menuntut perlindungan Kekayaan Intelektual agar terlindung dari persaingan-persaingan yang tidak sehat.

Kekayaan Intelektual (selanjutnya disingkat $\mathrm{KI}$ ) menjadi isu yang semakin menarik untuk dikaji

${ }^{1}$ Gustina, "Etika Bisnis Suatu Kajian Nilai dan Moral dalam Bisnis", Jurnal Ekonomi dan Bisnis, Volume 3, Nomor 2, Oktober 2008, Hlm. 139 karena perannya menentukan laju percepatan pembangunan nasional dalam era globalisasi. Walaupun merupakan Hak Privat (Private Rights), KI melayani dan menyumbang pada dunia usaha termasuk berurusan dengan kelompok Usaha Mikro Kecil dan Menengah (UMKM).

Kekayaan Intelektual merupakan terjemahan dari Intellectual Property Rights (IPR) merupakan Hak Kekayaan yang lahir dari kemampuan intelektual manusia yang ada dalam lingkup ilmu pengetahuan, seni dan sastra. Kekayaan Intelektual merupakan kreatifitas yang dihasilkan dari olah pikir manusia dalam rangka memenuhi kebutuhan dan kesejahteraan hidup manusia. Kreatifitas manusia yang muncul sebagai asset intelektual seseprang telah lama memberi pengaruh yang signifikan terhadap peradaban manusia, antara lain melalui penemuan-penemuan (invention) dan hasil-hasil di bidang karya cipta dan seni (art and literary work). ${ }^{2}$

Potensi dan Peran UMKM, selama ini belum tertangani secara serius, namun mampu menjadi penopang ekonomi bangsa dari masa krisis hingga saat ini. Sektor UMKM telah berperan sebagai Economic Safety Net dan juga Social Safety Net yang mampu menyerap tenaga kerja dalam jumlah yang besar sehingga turut mengurangi beban pengangguran nasional, membantu pengentasan kemiskinan serta memberi sumbangan yang berarti dalam Produk Domestik

\footnotetext{
${ }^{2}$ Kholis Roisah, 2015, Konsep Hukum Hak Kekayaan Intelektual (HKI) : Sejarah, Pengertian dan Filosofi Pengakuan HKI dari Masa ke Masa, Malang, Setara Press, hlm.1
} 
Bruto (PDB).

Dari beberapa bidang yang ada dalam sistem Kekayaan Intelektual (KI), pemanfaatan atas sistem Kekayaan Intelektual (KI) terutama mengenai masalah pendaftaran bidang-bidang Kekayaan Intelektual (KI) atas sektor UMKM yang dipunyai oleh para pengusaha dapat dikatakan masih sedikit. Masih sedikitnya minat UMKM Indonesia untuk mendaftarkan Kekayaan Intelektual karena masih memandang bahwa Kekayaan Intelektual (KI) bukan merupakan kebutuhan. Perilaku Bisnis UMKM Indonesia masih sangat tradisional, dan belum berpikir tentang Pelindungan Kekayaan Intelektual (KI) atas produk atau desain produknya. Kendala lainnya, disebabkan aksebilitas untuk mendaftarkan Kekayaan Intelektual tidak mudah, koordinasi dalam pelaksanaan antar instansi pemerintah belum tertata serta adanya birokrasi panjang dan biaya. Kurangnya sosialisasi Kekayaan Intelektual (KI) bagi setiap produk hasil karya UMKM juga sangat minim sehingga pelaku usaha ada yang sama sekali tidak tahu Kekayaan Intelektual (KI). Keadaan ini tentu mengkhawatirkan karena dalam dunia usaha selalu ada persaingan. Persaingan yang tidak sehat akan membuat pelaku usaha mengalami kekalahan dalam hal penemuan dan pemasaran produk. Karena itu penting kiranya Pelindungan Hukum bagi produkproduk UMKM dengan melandaskan pada Kekayaan Intelektual (KI).

Berdasarkan

uraian permasalahan di atas, maka peneliti merumuskan suatu permasalahan yang coba diteliti terkait dengan Penerapan Pelindungan Kekayaan Intelektual (KI) terhadap produk Usaha Mikro, Kecil dan Menengah (UMKM)? Serta Peranan
Pemerintah dalam mewujudkan Pelindungan Kekayaan Intelektual (KI) terhadap produk-produk UMKM ?

\section{B. METODE PENELITIAN}

Penelitian mengenai penerapan kekayaan intelektual (KI) terhadap UMKM sebagai upaya mewujudkan persaingan bisnis berkeadilan merupakan Penelitian Hukum Normatif Empiris, yaitu penelitian yang memperhatikan bahwa hukum bekerja pada segi kaidah/norma/normwissenschaft yaitu perundang-undangan yang berkaitan dengan hak cipta, merek, paten, desain industri, rahasia dagang, indikasi geografis yang tidak terlepas dari unsur sosial/empiris yaitu kenyataan adanya Produk Unggulan UMKM di Kabupaten Serang Provinsi Banten sehingga perlu diketahui perlindungannya sesuai tujuan penelitian.

Adapun pendekatan dalam penelitian yaitu mengenai berlakunya hukum positif. $^{3}$ Yaitu berlakunya perundang-undangan KI yang relevan dengan Produk Unggulan Daerah yaitu UMKM dengan cara melakukan analisa/analisis terhadap data hukum dan hasil yang diperoleh dalam penelitian dengan cara mengetahui makna yang dikandung oleh istilahistilah yang digunakan dalam peraturan perundang-undangan secara konsepsional, sekaligus mengetahui masalah-masalah yang terjadi dalam penerapan/pelaksanaan serta pendaftaran Kekayaan Inteletual (KI) nya.

Sumber Data yang digunakan dalam penelitian ini adalah : (a). Data sekunder, yaitu data yang diambil dari sumber kedua atau data pustaka, dalam wujud bahan hukum primer, bahan hukum sekunder dan bahan tersier.

\footnotetext{
3 Soerjono Soekanto, 1999, Pengantar Penelitian Hukum, UI Press, Jakarta, hlm. 80.
} 
Menurut Soekanto dan Mamudji :

1. Bahan Hukum Primer yakni bahan hukum yang mengikat, terdiri dari: peraturan perundang-undangan yang diurut berdasarkan hierarkhi Undang-Undang Dasar 1945, Undang-Undang (UU) meliputi : Undang-Undang Nomor 7 Tahun 1994 tentang Pengesahan Persetujuan Pembentukan Organisasi Perdagangan Dunia dan Perundang-undangan KI, dan traktat mengenai Persetujuan TRIP's (Agreement on Trade Related Aspect of Intellectual Property Rights);

2. Bahan hukum sekunder merupakan penjelasan dari bahan hukum primer terdiri dari buku-buku teks (textbooks) yang ditulis oleh ahli hukum yang berpengaruh (de herseende leer), jurnal-jurnal hukum, pendapat para sarjana, kasus-kasus hukum, yurisprudensi dan hasilhasil simposium mutakhir yang berkaitan dengan topik penelitian.

3. Bahan hukum tersier merupakan penjelasan dari bahan hukum primer dan sekunder terdiri dari kamus hukum yaitu Black's Law Dictionary. Adapun (b). Data primer, yaitu data yang diambil langsung dari sumber pertama yaitu data lapangan atau field research. Data primer itu berupa perilaku hukum baik individu ataupun kelompok maupun dalam wujud pendapat, persepsi, atau sikap individu maupun

4 Soerjono Soekanto dan Sri Mamudji, 2003, Penelitian Hukum Normatif, Penerbit PT. Rajawali Press, hlm. 10 kelompok $^{5}$ sedangkan data primer penelitian ini diperoleh dari wawancara yaitu metode yang digunakan dimana interviewer bertatap muka langsung dengan responden untuk menanyakan perihal pribadi responden, fakta-fakta yang ada dan pendapat (opinion) maupun persepsi diri responden dan bahkan saran-saran responden ${ }^{6}$.

\section{KERANGKA KONSEPTUAL 1. PengertianUsaha Mikro, Kecil, dan Menengah (UMKM)}

Usaha Mikro, Kecil, dan Menengah (UMKM) memiliki definisi yang berbeda pada setiap literatur menurut beberapa instansi atau lembaga bahkan Undang-undang. Undang-undang Nomor 20 Tahun 2008 pasal 6 membagi kriteria UMKM berdasarkan jumlah kekayaan bersih dan hasil penjualan tahunan. Sedangkan Badan Pusat Statistik (BPS) membagi kriteria UMKM berdasarkan jumlah tenaga kerja mereka. $^{7}$

Dalam Undang-Undang Nomor 20 Tahun 2008 tentang Usaha Mikro Kecil Menengah yang diundangkan pada tanggal 4 Juli 2008, berlaku pada tanggal diundangkan. Menurut Pasal 1 UU UMKM, Usaha Mikro adalah usaha produktif milik orang perorangan dan/atau badan usaha perorangan yang memenuhi kriteria Usaha Mikro sebagaimana

\footnotetext{
5 Oloan Sitorus dan Darwinsyah Minin, 2006, Cara Penyelesaian Karya Ilmiah di Bidang Hukum, Penerbit Mitra Kebijakan Tanah Indonesia, Yogyakarta, hlm. 32

${ }^{6}$ Bambang Waluyo, 1996, Penelitian Hukum dalam Praktek, Penerbit Sinar Grafika, Jakarta, HLm. 57

7 Dani Danuar Tri U., Darwanto, “ Pengembangan Usaha Mikro Kecil dan Menengah (UMKM) Berbasis Ekonomi Kreatif di Kota Semarang", Diponegoro Journal of Economics, Volume 2 Nomor 4, 2013, hlm. 2
} 
diatur dalam Undang-Undang ini. Usaha Kecil adalah usaha ekonomi produktif yang berdiri sendiri, yang dilakukan oleh orang perorangan atau badan usaha yang bukan merupakan anak perusahaan atau bukan cabang perusahaan yang dimiliki, dikuasai, atau menjadi bagian baik langsung maupun tidak langsung dari Usaha Menengah atau Usaha Besar yang memenuhi kriteria Usaha Kecil sebagaimana dimaksud dalam Undang-Undang ini. Sedangkan Usaha Menengah adalah usaha ekonomi produktif yang berdiri sendiri, yang dilakukan oleh orang perorangan atau badan usaha yang bukan merupakan anak perusahaan atau cabang perusahaan yang dimiliki, dikuasai, atau menjadi bagian baik langsung maupun tidak langsung dengan Usaha Kecil atau Usaha Besar dengan jumlah kekayaan bersih atau hasil penjualan tahunan sebagaimana diatur dalam Undang-Undang ini.

Beberapa ahli pernah menjelaskan tentang definisi UMKM, diantaranya Rudjito, pengertian UMKM adalah usaha yang punya peranan penting dalam perekonomian negara Indonesia, baik dari sisi lapangan kerja yang tercipta maupun dari sisi jumlah usahanya. Menurut Ina Primiana, pengertian UMKM adalah pengembangan empat kegiatan ekonomi utama yang menjadi motor penggerak pembangunan Indonesia, yaitu; Industri manufaktur, Agribisnis, Bisnis kelautan, Sumber daya manusia Selain itu, Ina Primiana juga mengatakan bahwa UMKM dapat diartikan sebagai pengembangan kawasan andalan untuk mempercepat pemulihan perekonomian untuk mewadahi program prioritas dan pengembangan berbagai sektor dan potensi. Sedangkan usaha kecil merupakan peningkatan berbagai upaya pemberdayaan masyarakat.

UMKM (Usaha Mikro Kecil dan Menengah) memiliki fungsi yang sangat strategis baik secara sosial ekonomi maupun sosial politik sebagai berikut : ${ }^{8}$

1. Fungsi Sosial Ekonomi, sektor ini antara lain menyediakan barang dan jasa bagi konsumen berdaya beli rendah sampai sedang, menyumbangkan lebih dari sebagian pertumbuhan ekonomi serta kontributif perolehan devisa negara.

2. Fungsi Sosial Politik, sektor ini juga sangat penting terutama dalam penyerapan tenaga kerja serta upaya pengentasan kemiskinan, karena sifat sebarannya dan keterkaitannya yang erat dengan sektor pertanian juga sangat potensial untuk mendorong kemajuan ekonomi pedesaan.

Kathrin Muller, et., al.,(2008) mengemukakan tiga peran industri kreatif terhadap inovasi ekonomi dalam penelitiannya di Eropa. Yang pertama, industri kreatif adalah sumber utama dari ide-ide inovatif potensial yang berkontribusi terhadap pembangunan/inovasi produk barang dan jasa. Kedua, industri kreatif menawarkan jasa yang dapat digunakan sebagai input dari aktivitas inovatif perusahaan dan organisasi baik yang berada di dalam lingkungan industri kreatif maupun yang berada diluar industri kreatif. Terakhir, industri kreatif menggunakan teknologi secara intensif sehingga dapat mendorong inovasi dalam

\footnotetext{
${ }^{8}$ Candra Purnama, Perlindungan Hukum Produk UMKM Melalui HKI (Hak Kekayaan Intelektual), dinkop_umkm.jatengprov.go.id., diunduh pada 13 Maret 2018 Pkl. 12.03
} 
bidang teknologi tersebut. ${ }^{9}$

\section{Pengertian Persaingan}

Secara umum persaingan didefinisikan sebagai proses sosial yang melibatkan individu atau kelompok yang saling berlomba dan berbuat sesuatu untuk mencapai kemenangan tertentu. Persaingan dapat terjadi apabila beberapa pihak menginginkan sesuatu yang terbatas atau sesuatu yang menjadi pusat perhatian umum. Persaingan berlangsung tanpa ancaman atau kekerasan.

Dalam ekonomi, persaingan atau kompetisi adalah bersaingnya para penjual yang sama-sama berusaha mendapatkan keuntungan, pangsa pasar, dan jumlah penjualan. Para penjual biasanya berusaha mengungguli persaingan dengan membedakan harga, produk, distribusi dan promosi. https://id.wikipedia.org/wiki/Persaingan (ekonomi)

Menurut Undang-undang Nomor 5 Tahun 1999 tentang Persaingan Usaha Tidak Sehat dan Anti Monopoli yang dimaksud dengan "Persaingan Curang" (Persaingan Tidak Sehat) adalah suatu persaingan antar pelaku usaha dalam menjalankan kegiatan produksi dan atau pemasaran barang atau jasa yang dilakukan dengan cara-cara yang tidak jujur atau dengan cara melawan hukum atau menghambat persaingan usaha. ${ }^{10}$

Persaingan berasal dari bahasa Inggris yaitu competition yang artinya persaingan itu sendiri atau kegiatan bersaing, pertandingan, dan kompetisi.Persaingan adalah ketika organisasi atau perorangan berlomba untuk mencapai tujuan yang diinginkan seperti konsumen, pangsa

\footnotetext{
${ }^{9}$ Dani Danuar Tri U., Darwanto, Op., Cit.,hlm. 3

10 Munir Fuady, 2013, Pengantar Hukum Bisnis, Bandung, PT. Citra Aditya Bakti, hlm. 213
}

pasar,peringkat survei, atau sumber daya yang dibutuhkan.3 Sedangkan dalam kamus manajemen, persaingan adalah usaha-usaha dari 2 pihak/lebih perusahaan yang masing-masing bergiat "memperoleh pesanan" dengan menawarkan harga/syarat yang paling menguntungkan.

Sementara itu Dalam kamus Manajemen persaingan bisnis pengertian atau definisi Persaingan sehat (healthy competition), persaingan antara perusahaan-perusahaan atau pelaku bisnis yang diyakini tidak akan menuruti atau melakukan tindakan yang tidak layak dan cenderung mengedepankan etika-etika bisnis.

Adapun Perjanjian dan Kegiatan yang Dilarang dalam ruang lingkup dari pengaturan Persaingan Tidak Sehat dan Anti Monopoli adalah: ${ }^{11}$

1. Perjanjian yang Dilarang
a. Oligopoli
b. Penetapan Harga
c. Pembagian Wilayah
d. Pemboikotan
e. Kartel
f. Trust
g. Oligopsoni
h. Integrasi Vertikal
i. Perjanjian Tertutup
j. Perjanjian dengan Pihak Luar Negeri

2. Kegiatan yang Dilarang
a. Monopoli
b. Monopsoni
c. Penguasaan Pangsa Pasar
d. Persekongkolan

Sebelum dikeluarkannya Undangundang Nomor 5 Tahun 1999 sebenarnya pengaturan mengenai Persaingan Usaha Tidak Sehat didasarkan pada pasal 1365 KUHPerdata mengenai Perbuatan Melawan Hukum dan pasal 382 bis KUHPidana

\footnotetext{
11 Ibid., hlm. 215
} 
"Barangsiapa untuk mendapatkan, melangsungkan atau memperluas hasil perdagangan atau perusahaan milik sendiri atau oranglain, melakukan perbuatan curang untuk menyesatkan khalayak umum atau seseorang tertentu, diancam karena persaingan curang dengan pidana penjara paling lama satu tahun empat bulan atau pidana denda paling banyak tiga belas ribu lima ratus rupiah, bila perbuatan itu menimbulkan kerugian bagi konkuren-konkuren orang lain itu." 12

\section{Pengertian Kekayaan Intelektual} (KI)

Intellectual Property is a phrase that refers to propietary rights in creations of the mind. ${ }^{13}$ Intellectual World Property Organization (WIPO) disebut : "creation of the mind" yang berarti suatu karya manusia yang lahir dengan curahan tenaga, karsa, cipta, waktu dan biaya. Ditinjau dari substansinya, HKI adalah "product of mind". Oleh karena itu, setiap karya intelektual patut diakui, dihormati, dilindungi dan dihargai baik secara moral maupun secara hukum. ${ }^{14}$

$\begin{array}{ccc}\text { Hak } & \text { Kekayaan } & \text { Intelektual } \\ \text { (sekarang } & \text { disebut } & \text { Kekayaan }\end{array}$

Intelektual) merupakan hak eksklusif yang diberikan negara kepada para kreator, inventor atau pendesain atas hasil kreasi atau temuannya yang mempunyai nilai komersial, baik langsung secara otomatis atau melalui pendaftaran pada instansi terkait sebagai penghargaan, pengakuan hak

12 Sulasno, 2009, Hukum Bisnis, Serang-Banten : Unsera Press, hlm. 86

13 John R. Thomas, "Intellectual Property in Industrial Designs : Issues in Innovation and Competition", Congressional Research Service, 7-5700, January 6, 2010, Hlm. 1

${ }^{14}$ Agus Mardiyanto, et.al., "Implementasi Perlindungan Hukum Terhadap Hak Kekayaan Intelektual Masyrakat Asli / Tradisional di Kabupaten Purbalingga" Jurnal Dinamika Hukum, Volume 3 Nomor 1, Januari 2013, hlm. 24 yang patut diberikan perlindungan hukum. 15

Kekayaan Intelektual memiliki 2 (dua) aspek utama, yaitu : ${ }^{16}$

1. Proses dan Produk ini meliputi berbagai bidang secara luas, mulai dari bidang seni dan sastra hingga invensi dan inovasi di bidang teknologi serta segala bentuk lainnya yang merupakan hasil dari proses kreativitas manusia lewat cipta, rasa, dan karsanya.

2. Karya cipta atau invensi tersebut menimbulkan hak milik bagi pencipta atau penemunya. Sifatnya sebagai hak milik, maka karenanya hak seorang pencipta atau penemu atas karya ciptanya haruslah dilindungi.

Adapun Perundang-undangan yang mengatur dalam lingkup bidang Kekayaan Intelektual (KI) yang diatur di Indonesia yaitu : ${ }^{17}$

1. Undang-undang Hak Cipta (UU Nomor 28 Tahun 2014),

2. Undang-undang tentang Merek (UU Nomor 20 Tahun 2016),

3. Undang-undang tentang Paten (UU Nomor 13 Tahun 2016),

4. Undang-undang tentang Rahasia Dagang (UU Nomor 30 Tahun 2000),

5. Undang-undang tentang Desain Industri (UU Nomor 31 Tahun 2000),

6. Undang-undang tentang Desain Tata Letak Sirkuit Terpadu (UU

\footnotetext{
15 Andy Prasetyo Utomo, "Pemetaan Merek dan Desain Industri UMKM Berpotensi HKI di Kabupaten Kudus Berbasis Sistem Informasi Geografis Menggunakan Google MAP API", Prosiding Seminar Nasional Multi Disiplin Ilmu dan Call for Papers Unisbank (SENDI-U), ISBN : 978-979-364981-8.

16 Kholis Roisah, Op. Cit., Hlm. 7

17 Nahrowi, "Plagiat dan Pembajakan Karya Cipta dalam Hak Kekayaan Intelektual", Salam : Jurnal Filsafat dan Budaya Hukum, 17 November 20014, hlm. 228
} 
Nomor 32 Tahun 2000), dan

7. Undang-undang tentang Perlindungan Varietas Tanaman (UU Nomor 29 Tahun 2000).

\section{Prinsip-prinsip} Intelektual (KI)

Kekayaan

1. Prinsip ekonomi, yakni hak intelektual berasal dari kegiatan kreatif suatu kemauan daya pikir manusia yang diekspresikan dalam berbagai bentuk yang akan memeberikan keuntungan kepada pemilik yang bersangkutan.

2. Prinsip Keadilan.

Prinsip keadilan, yakni di dalam menciptakan sebuah karya atau orang yang bekerja membuahkan suatu hasil dari kemampuan intelektual dalam ilmu pengetahuan, seni, dan sastra yang akan mendapat perlindungan dalam pemiliknya

3. Prinsip Kebudayaan.

Prinsip kebudayaan, yakni perkembangan ilmu pengetahuan, sastra, dan seni untuk meningkatkan kehidupan manusia. Pengakuan atas karya, karsa, cipta manusia sebagai perwujudan suasana yang mampu membangkitkan semangat dan minat untuk mendorong ciptaan atau penemuan baru yang berguna bagi peningkatan taraf kehidupan peradaban dan martabat manusia.

4. Prinsip Sosial.

Prinsip sosial ( mengatur kepentingan manusia sebagai warga Negara ), artinya hak yang diakui oleh hukum dan telah diberikan kepada individu merupakan satu kesatuan sehingga perlindungan diberikan bedasarkan keseimbangan kepentingan individu dan masyarakat.

\section{Keadilan}

Suatu keadaan yang adil adalah suatu keadaan dimana dapat tercapai apabila warga masyarakat melaksanakan tugas dan kewajiban yang sesuai dengan kedudukan serta peranannya dalam masyarakat. ${ }^{18}$ Begitupun dalam dunia bisnis, diharapkan tercapai keadaan dimana kondisi pertumbuhan kegiatan bisnis berlangsung sesuai dengan tugas dan kewajiban pelaku usaha. Tidak ada pelaku usaha yang berlaku curang dan melampaui hak nya dan diharapkan tidak merugikan pelaku usaha lain.

Rawls menekankan pentingnya melihat keadilan sebagai kebajikan utama yang harus dipegang teguh dan sekaligus menjadi semangat dasar dari pelbagai lembaga sosial dasar suatu masyarakat. Bagi Rawls memperlakukan keadilan sebagai kebajikan pertama, berarti memberikan kesempatan secara adil dan sama bagi setiap orang untuk mengembangkan serta menikmati harga diri dan martabatnya sebagai manusia. Sementara itu, harga diri dan martabat manusia tidak bisa diukur dengan kekayaan ekonomis sehingga harus dimengerti jauh bahwa keadilan lebih luas melampaui status ekonomis seseorang. ${ }^{19}$

\section{PEMBAHASAN}

1. Penerapan Kekayaan Intelektual (KI) terhadap Usaha Mikro, Kecil, dan Menengah (UMKM)

$$
\text { Kekayaan Intelektual }
$$

merupakan kreatifitas yang dihasilkan dari hasil olah pikir manusia dalam rangka memenuhi

18 Soerjono Soekanto, 2016, Pokok-Pokok Sosiologi Hukum, Jakarta, PT. RajaGrafindo Persada, hlm. 188

19 Andre Ata Ujan, 2001, Keadilan dan Demokrasi : Telaah Filsafat Politik John Rawls, Jogjakarta, Kanisius, hlm.23 
kebutuhan dan kesejahteraan manusia. Sehubungan kekayaan intelektual tersebut merupakan hasil dari pemikiran manusia, maka perlu adanya pengaturan untuk memberikan perlindungan hukum. Kemampuan intelelektual manusia yang berupa daya cipta, rasa, dan karsanya menghasilkan karya karyanya di bidang ilmu pengetahuan, seni dan teknologi. Bidang bidang tersebut bila dilihat dari sifatnya dapat dikategorikan kekayaani ntelektual komunal dan kekayaan intelektual personal. Keduanya bisa dimanfaatkan secara ekonomi dalam rangka meningkatkan dan menumbuhkan usaha usaha atau bisnis yang menuju pada kesejahteraan yang berkeadilan. Dengan adanya kekayaan intelektual tersebut diharapkan mampu untuk bersaing dengan produk produk luar negeri yang telah lama beredar bebas di pasaran.

Demikian juga dengan produk produk usaha mikro kecil, dan menengah perlu mendapatkan perhatian yang serius dari pemerintah dan adanya jaminan yang pasti.Dengan demikian daya saing dan kemampuan UMKM perlu lebih ditingkatkan agar dapat memanfaatkan sistem perdagangan bebas yang berlangsung saat ini. Sistem itu dapat dimanfaatkan sebagai peluang untuk memperkenalkan produk-produk unggulan mereka di pasar global, ikut serta bahkan berperan serta secara nyata dalam sistem tersebut. Dalam kondisi peluang pasar menjadi lebih terbuka, liberlisme perdagangan tidaklah otomatis dapat membantu bahkan menjadi ancaman bagi UMKM. Untuk mengantisipasi ancaman tersebut
UMKM dituntut kreatif dan inovatif berani mengambil langkah dengan menghasilkan produk barang yang dari segi kualitasnya tidak kalah dengan produk dari perusahaan besar. ${ }^{20}$

Atas produk industriindustri UMKM dapat diberikan Pelindungan Kekayaan Intelektual (KI) berupa:

1. Perlindungan Hak Cipta atas Karya-karya Kreatif Pencipta dalam Ilmu Pengetahuan maupun Karya-karya Seni;

2. Pemberian Merek Dagang maupun Merek Jasa atas Gambar, Nama, Kata, Huruf, Angka, Susunan Warna atau Kombinasi dari Unsur-unsur tersebut yang mempunyai daya pembeda dan digunakan dalam kegiatan perdagang an barang atau jasa;

3. Pemberian Paten Sederhana atas teknologi yang ditemukan invensinya berupa produk atau

4. Alat yang Baru dan mempunyai nilai kegunaan praktis disebabkan oleh Bentuk, Konfigurasi, Konstruksi, atau Komponennya;

5. Kreasi atas Desain Industri berupa Bentuk, Konfigurasi, Komposisi Garis atau Warna yang memberikan kesan estetis dan dapat diterapkan pada komoditas Industri dan Kerajinan Tangan;

6. Rahasia Dagang atas informasi yang tidak diketahui umum di bidang teknologi dan atau bisnis, bernilai ekonomi, berguna dalam kegiatan usaha dan dijaga kerahasiaannya oleh pemilik rahasia dagang;

Dengan di berikannya dan

\footnotetext{
${ }^{20}$ Candra Purnama, Op. Cit.
} 
penerapan kekayaan intelektual terhadap usaha mikro kecil dan menengah tersebut terwujud maka dapat dipastikan akan dapat mewujudkan suasana yang lebih baik dan sehat untuk tumbuh dan berkembangnya gairah mencipta dalam bidang ilmu pengetahuan, seni dan sastra (dapat mencegah persaingan usaha yang tidak sehat/unfire compettion) serta dapat meminimalisir usaha usaha penyimpangan atau pelanggaran yang dilakukan oleh orang orang yang tidak bertanggung jawab.

Selain itu penerapan kekayaan intektual terhadap usaha mikro kecil, dan menengah sebagai upaya dalam bisnis yang menuju sejahtera maka di dasarkan pada prinsip prinsip kekayaan intelektual, yaitu prinsip keadilan, ekonomi, kebudayaan, dan sosial.

\section{Peranan Pemerintah dalam Mewujudkan Pelindungan Kekayaan Intelektual (KI) yang berkeadilan}

Indonesia secara resmi telah memasuki globalisasi perdagangan dengan diberlakukannya Convention Establishing The World Trade Organization (Konvensi WTO) termasuk di dalamnya Agreement on Trade Related Aspects of Intellectual Property Rights (Persetujuan TRIPs). Hal ini ditindaklanjuti dengan meratifikasi Undang-undang Nomor 7 Tahun 1994 tentang Pengesahan Persetujuan Pembentukan Organisasi Perdagangan Dunia atau Agreement Establishing The WTO. Dalam Konvensi tersebut dimuat persetujuan mengenai aspek-aspek dagang dari Hak Kekayaan Intelektual yang tertuang dalam TRIPs. Pasal 7 dari Undang-undang tersebut menyebutkan bahwa perlindungan dan penegakan hukum Hak Kekayaan Intelektual (HKI) bertujuan untuk mendorong timbul dan berkembangnya inovasi, pengalihan, dan penyebaran untuk manfaat ekonomi bangsa-bangsa dunia. ${ }^{21}$

Pemerintah telah melakukan upaya untuk lebih meningkatkan pemanfaatan Kekayaan Intelektual (KI) terhadap UMKM misalnya dalam bentuk pemberian fasilitas kepada industri untuk mendaftarkan desain industrinya, hak cipta, dan desain produk, bahkan sekarang pendaftaran sudah dapat dilakukan secara online. Departemen Perindustrian (Depperin) sudah membentuk klinik konsultasi bagi UMKM yang memerlukan bantuan untuk mendaftarkan Kekayaan Intelektual produknya. Ada juga kebijakan yang dikeluarkan oleh pemerintah dalam biaya pengurusan hak paten untuk desain agar dapat dijangkau pelaku usaha dalam bentuk diskon/potongan pembayaran atas produk yang akan di daftarkan. Di sisi lain pihak KADIN pun juga membantu meringankan komponen biaya yang dinilai para UMKM memberatkan. Sejak Undang-Undang Nomor 20 Tahun 2008 tentang Usaha Mikro Kecil Menengah diundangkan pada tanggal 4 Juli 2008, berlaku pada tanggal diundangkan, makin memperkuat posisi UMKM dalam menunjukkan kiprahnya.

Sistem pelindungan hukum dengan mengajukan permohonan pendaftaran adalah konstitutif yang dikenal dengan sistem First to File yaitu pendaftar pertama (yang memenuhi persyaratan yang telah ditentukan) yang akan mendapatkan sertifikat. 22

21 Fajar Nurcahya Dwi Putra, "Perlindungan Hukum bagi Pemegang Hak atas Merek terhadap Perbuatan Pelanggaran Merek", Jurnal Ilmu Hukum, Edisi Januari-Juni 2014, hlm. 103

22 Yuliasih, "Perlindungan Hukum Desain Industri dalam Pelaksaan Prinsip Keadilan Menurut Teori 
Pelindungan hukum hendaknya terhadap kekayaan intelektual (KI) terhadap produk produk UMKM harus sesuai dengan tujuan Negara yang tertuang dalam pembukaan UUD 1945 alenia ke -4 yaitu untuk memajukan kesejahteraan umum. Sehubungan dengan tujuan Negara tersebut maka di kemukakan oleh Oleh : Dr. Rio Christiawan,S.H.,M.Hum.,M.Kn., Advokat dan Dosen Hukum Bisnis Universitas Prasetiya Mulyaby dalam SWAOnline - May 1, 2018 sebagai berikut : Kesejahteraan Bangsa Melalui Kekayaan Intelektual Revitalisasi aturan hak atas kekayaan intelektual ini sejalan dengan program nawacita Presiden Joko Widodo yaitu meningkatkan produktivitas rakyat dan daya saing di pasar internasional sehingga bangsa Indonesia bisa maju dan bangkit setara dengan bangsa yang lainnya. Pada konteks ini pemerintah harus mengubah paradigma regulasi untuk memberi kemudahan dan insentif bagi rakyat Indonesia dibanding warga negara asing maupun korporasi asing dalam hal perolehan hak atas kekayaan intelektual. Dengan demikian produk yang dihasilkan bangsa Indonesia akan memiliki proteksi dan daya saing baik di dalam negeri maupun di luar negeri.

Dengan adanya insentif yang diperoleh dari hak atas kekayaan intelektual maka kekayaan intelektual akan dapat mewujudkan kemandirian ekonomi sebagimana tujuan negara kesejahteraan dengan tumbuhnya sektor-sektor strategis ekonomi domestik. Paradigma terhadap hak atas kekayaan intelektual saat ini telah berubah, dari hak sebagai pengakuan esklusif menjadi hak sebagai kekayaan kebendaan sehingga dapat dipergunakan sebagai instrument modal atau jaminan dalam industri kecil dan menengah .

Meskipun saat ini telah ada terobosan yang patut diapresiasi yakni menggunakan kekayaan intelektual sebagai jaminan, tetapi

Keadilan John Rawls (Studi Kasus Putusan Nomor 35 PK/PDT.SUS-hki/2014)", Notarius, Edisi 08 Nomor 2, September 2015, hlm. 154 regulasi perbankan belum mengatur secara eksplisit terkait kapasitas kekayaan intelektual untuk dapat dipergunakan sebagai jaminan. Pemerintah dalam hal ini harus dapat menjembatani kebutuhan pembiayaan untuk pertumbuhan ekonomi dengan menggunakan kekayaan intelektual sebagai jaminan. Dalam hal ini antara Dirjen KI, BI dan OJK harus dapat merumuskan regulasi terkait hak atas kekayaan intelektual sebagai agunan pembiayaan.

Dengan dapat teratasinya gap tersebut maka selain kekayaan intelektual dapat membawa kesejahteraan bagi seluruh bangsa Indonesia sekaligus memberdayakan usaha kecil menengah sebagaimana dicanangkan Presiden dalam Making Indonesia 4.0. Paradigma revitalisasi aturan hak atas kekayaan intelektual dan implementasinya harus diarahkan pada kesejahteraan seluruh bangsa, sehingga revitalisasi aturan hak atas kekayaan intelektual dapat berjalan Bersamasama dengan program prioritas nasional yaitu Making Indonesia 4.0. Pada akhirnya keseluruhan tujuan dari program tersebut adalah paradigma baru di bidang hak atas kekayaan intelektual yaitu mewujudkan kesejahteraan melalui kemandirian bangsa. Masyarakat pada umumnya saat ini jauh lebih membutuhkan akses akan kesejahteraan melalui kemandirian ekonomi, oleh sebab itu pemerintah harus mengarahkan regulasi hak atas kekayaan intelektual pada akses tersebut sehingga tercapai keadilan sosial bagi seluruh rakyat Indonesia. Namun demikian menurut (Irawan, 2011 : 11) pelindungan Kekayaan Intelektual (KI) yang ingin menciptakan persaingan yang kompetitif dalam menghasilkan invensi baru atau karya intelektual lain ternyata tidak sepenuhnya benar. Dampak yang muncul dalam penerapan ketentuan dalam Kekayaan Intelektual yang mengedepankan dalam aspek ekonomi (perdagangan) justru semakin mahalnya biaya untuk memunculkan investasi baru karena harus mendapatkan lisenci dari banyak invensi yang sudah ada sebelumnya dan membutuhkan waktu relatif lama 
Dengan pelindungan hukum terhadap produk produk UMKM melalui pemanfaatan kekayaan intelektual (KI) maka persaingan bisnis menjadi lebih kondusif, aman, nyaman dan kepastian hokum lebih jelas mana yang sudah terlindungan dan mana yang beleum mendapatkan perlindungan hokum oleh Negara. Konsekwensi hukum dan konsekwensi logispun juga berbeda.

\section{E. KESIMPULAN}

Berdasarkan uraian dalam pembahasan tersebut diatas maka dapat diambil simpulan sebagai berikut :

1. Penerapan Pelindungan Hukum terhadap Produk UMKM bisa dilihat dari aspek pemasaran, aspek produksi, aspek Sumber Daya Manusia dan managerial, aspek legalitas, aspek keuangan dan permodalan, aspek ketenagakerjaan termasuk juga aspek Kekayaan Intelektual. Kekayaan Intelektual menjadi sangat penting dalam rangka member rasa pasti dan aman.

2. Peranan pemerintah dalam mewujudkan pelindungan Kekayaan Intelektual yang adil nan sejahtera. Ada beberapa kebijakan Pemerintah yang digulirkan diantaranya terkait kemudahan yang diberikan dimulai saat pendaftaran hingga potongan pembayaran merupakan bentuk Pelindungan terhadap produk-produk UMKM dan sebagai bentuk upaya mengenalkan Kekayaan Intelektual (KI) sebagai solusi agar produkproduk UMKM terlindungi. Kesadaran pelaku UMKM untuk mendaftarkan produknya juga merupakan hal yang harus dilakukan dalam hubungan terciptanya produk berbasis Kekayaan Intelektual (KI).

\section{DAFTAR PUSTAKA}

\section{Buku-buku :}

Fuady, Munir. 2013, Pengantar Hukum Bisnis, Bandung, PT. Citra Aditya Bakti

Irawan Chandra, 2011, Politik Hukum Hak Kekayaan Intelektual Indonesia, Penerbit CV. Mandar Maju Cetakan 1, Mei

Roisah, Kholis. 2015, Konsep Hukum Hak Kekayaan Intelektual (HKI) : Sejarah, Pengertian dan Filosofi Pengakuan HKI dari Masa ke Masa, Malang, Setara Press

Soekanto, Soerjono, 2016, Pokok-Pokok Sosiologi Hukum, Jakarta, PT. RajaGrafindo Persada.

Sulasno, 2009, Hukum Bisnis, Serang-Banten : Unsera Press

Ujan, Andre Ata. 2001, Keadilan dan Demokrasi : Telaah Filsafat Politik John Rawls, Jogjakarta, Kanisius.

Jurnal :

Darwanto, Dani Danuar Tri U., Pengembangan Usaha Mikro Kecil dan Menengah (UMKM) Berbasis Ekonomi Kreatif di Kota Semarang, (Diponegoro Journal of Economics, Volume 2 Nomor 4, 2013).

Gustina, 2008, Etika Bisnis Suatu Kajian Nilai dan Moral dalam Bisnis, (Jurnal Ekonomi dan Bisnis, Volume 3, Nomor 2, Oktober 2008)

Mardiyanto, Agus., et.al., 2013, Implementasi Perlindungan Hukum Terhadap Hak Kekayaan Intelektual Masyrakat Asli / Tradisional di Kabupaten Purbalingga (Jurnal Dinamika Hukum, Volume 3 Nomor 1, Januari 2013)

Nahrowi, 2014, Plagiat dan Pembajakan Karya Cipta dalam Hak Kekayaan Intelektual, (Salam : Jurnal Filsafat dan Budaya Hukum, 17 November 2014)

Rio Christiawan,S.H.,M.Hum.,M.Kn. Dr, Advokat dan Dosen Hukum Bisnis Universitas Prasetiya Mulyaby dalam SWAOnline - May 1, 2018 
Putra, Fajar Nurcahya Dwi, 2014. Perlindungan Hukum bagi Pemegang Hak atas Merek terhadap Perbuatan Pelanggaran Merek, ( Jurnal Ilmu Hukum, Edisi Januari-Juni 2014)

Thomas, John R., 2001. Intellectual Property in Industrial Designs : Issues in Innovation and Competition, (Congressional Research Service, 75700, January 6, 2010)

Utomo, Andy Prasetyo. "Pemetaan Merek dan Desain Industri UMKM Berpotensi HKI di Kabupaten Kudus Berbasis Sistem Informasi Geografis Menggunakan Google MAP API", Prosiding Seminar Nasional Multi Disiplin Ilmu dan Call for Papers Unisbank (SENDI-U), ISBN : 978-9793649-81-8

Yuliasih, 2015. Perlindungan Hukum Desain Industri dalam Pelaksaan Prinsip Keadilan Menurut Teori Keadilan John Rawls (Studi Kasus Putusan Nomor 35 PK/PDT.SUS-HKI/2014), (Notarius, Edisi 08 Nomor 2, September 2015)

\section{Perundang-undangan :}

Undang-undang Republik Indonesia Nomor 5 Tahun 1999 tentang Persaingan Tidak Sehat dan Anti Monopoli

Undang-undang Republik Indonesia Nomor 20 Tahun 2008 tentang Usaha Mikro Kecil dan Menengah

Undang-undang Republik Indonesia Nomor 28 Tahun 2014 tentang Hak Cipta

Undang-undang Republik Indonesia Nomor 20 Tahun 2016 tentang Merek

Undang-undang Republik Indonesia Nomor 13 Tahun 2016 tentang Paten

Undang-undang Republik Indonesia Nomor 30 Tahun 2000 tentang Rahasia Dagang

Undang-undang Republik Indonesia Nomor 31 Tahun 2000 tentang Desain Industri

Undang-undang Republik Indonesia Nomor 32 Tahun 2000 tentang Desain Tata Letak Sirkuit Terpadu

Undang-undang Republik Indonesia Nomor 29 Tahun 2000 tentang Perlindungan Varietas Tanaman
Kitab Undang-undang Hukum Perdata

Kitab Undang-undang Hukum Pidana

Kamus :

Dalam kamus Manajemen persaingan

\section{Naskah Internet :}

Purnama, Candra. 2018, Perlindungan Hukum Produk UMKM Melalui HKI (Hak Kekayaan Intelektual), dinkop_umkm.jatengprov.go.id., diunduh pada 13 Maret 2018 Pkl. 12.03

https://id.wikipedia.org/wiki/Persaingan_(eko $\underline{\text { nomi) }}$ 
